\title{
Density currents in estuary models
}

\author{
Les courants de densité \\ dans les modèles d'estuaire
}

\author{
BY \\ W. A. PRICE, \\ PRINCIPAL SCIENTIFIC OFFICER \\ AND \\ Mary P. KENDRICK, \\ EXPERIMENTAL OFFICER
}

HYDRAULICS RESEARCH STATION, WALLINGFORD, BERKSHIRE

\begin{abstract}
Estuaries can conveniently be classified into highly-stratified, partly-mixed and well-mixed types. In the first two, siltation is likely to occur near the upstream limit of the "salt wedge," where there is no net drift of bed water landward or seauard. The authors subscribe to the less widely acknowledged view that density currents may also be one of the major factors determining the siltation pattern in a well-miaed estuary. Experimental results from work on models of the Thames and Mersey estuaries illustrate the different circulation patterns obtained with and without representation of the prototype salinity distribution.

The need to reproduce salinity/density currents in estuary models is discussed, with descriptions of methods of preparing concentrated brine, simple salinity control, model operational procedure, quicker ways of establishing correct longitudinal and vertical salinity distributions, salinity measurement and salt-water disposal methods. The possibility of employing the electro-dialysis process for control purposes is discussed also an alternative means of reproducing density currents. Finally practical suggestions are made for reducing seaward entry lengths of tidal models.
\end{abstract}

Lne classification utile des estuaires consiste a les grouper en «estuaires tres stratifies», en «estuaires anx eanx partiellement mélangées», et en «estuaties anx eala bien mélangées». Dans les denx premières catégories. l'envasement sera le plus susceptible de se produire au voisinage de la limite amont de la langue salée, à l'endroit où il ne se produit, près du fond, aucun moubement net de l'eau, vers la terre ou vers la mer. Les auteurs s'accordent avec une hypothèse moins généralement acceptée, suivant laquelle les courants de densite seraient aussi l'un des factears principaux déterminant le régime d'envasement dans un «estuaire aux eaux bien mélangées ». Des résultats d'études expérimentales effectuées sur des modeles des estuaires de la Tamise el de la Mersey mettent en évidence les différents schémas de circulation obtenus, avec et sans la reproduction, sur le modele, de la répartition de la salinité réelle.

Les auteurs examinent l'ulilité de représenter les courants de salinile et de densite dans les modèles d'estuaires, décrivent des procédés permettant la préparation d'une saumure concentrée, le réglage facile de la salinite, et présentent une vue d'ensemble du mode d'exploitation de ces modeles; ils indiquent comment il est possible d'établir plus rapidement les répartitions longitudinale et perticale correctes de la salinite, de mesurer cette salinité, et d'évacuer les eaux salées du modele. Suit un examen de la possibilité d'appliquer le principe de l'électro-dialyse au réglage du modèle, ainsi qu'un autre molyen de représenter les courants de densité. Finalement, les auteurs donnent des indications pratiques en vue de réduire les longueurs d'entrée aval des modèles à marée. 


\section{INTRODUCTION}

The mixing of fresh and salt water in an estuary controls the environment of many living organisms. It determines the distribution of waste products discharged to the estuary, the main areas of siltation, and can affect the siting of factories that use large quantities of water for industrial purposes. Any alteration in the salt water-fresh water balance, initiated by the diversion of tributaries, cut-off channels or extensive training works within the estuary, could therefore have serious repercussions both biologically and industrially. With the present state of knowledge it is not possible to make a reliable estimate of the effect of such works and therefore the engineer must have recourse to salt water-fresh water model studies.

There have been considerable advances in the techniques employed in hydraulic models during the last 30 years. Better instruments have made it possible to check their performance more accurately and in this way their usefulness has been increased. In addition certain deficiencies, previously unsuspected, have been exposed and certain effects, such as salinity/density currents, have been shown to be significant in many cases.

Earlier writers (Refs. [1], [2], [3] and [4]) have described the marked effect that the salinity distribution has on the estuarine circulation pattern, but have tended to stress its importance in the case of highly-stratified or partly-mixed estuaries. This note attempts to go one stage further by pointing out why it is sometimes essential to give particular attention to salinity/ density currents even in the case of well-mixed estuaries. The practical difficulties of reproducing the correct vertical and longitudinal salinity distributions in models of such estuarine systems are discussed, together with suggestions for their solution by the application of useful techniques.

\section{THE EFFECT OF SALINITY DISTRIBUTION IN ESTUARIES}

Fresh water entering an estuary dilutes the sea water that flows in and out by tidal action. Mixing takes place between the fresh and salt water and in this way a longitudinal and vertical salinity distribution is established.

The longitudinal salinity distribution in the
Thames estuary at H.W. and L.W. for an average fresh-water flow at Teddington Weir is shown in Figure 1. An observer at «A» will notice a rise in salinity on the flood tide, reaching a maximum shortly after H.W. and a fall in salinity on the ebb tide reaching a minimum

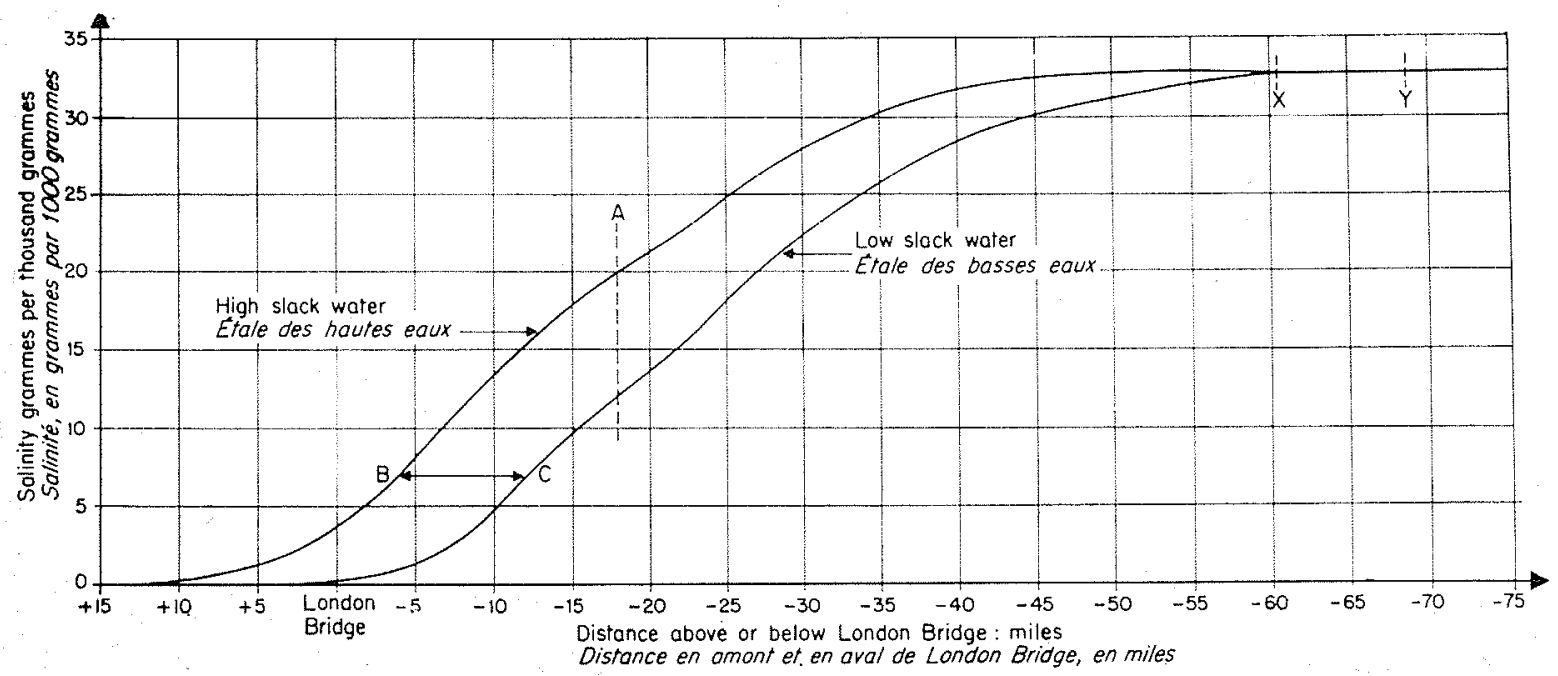

FIG. 1

Longitudinal salinity distributions in the Thames estuary.

Répartitions longitudinales de la salinité dans l'estuaire de la Tamise. 


\section{INTRODUCTION}

Le mélange des eaux fluviales avec de l'eau de mer, dans un estuaire, régit le milieu dans lequel évoluent de nombreux organismes vivants. Il détermine la répartition des débits solides évacués par les collecteurs d'égouts dans l'estuaire, et peut même influencer le choix des lieux d'implantation d'usines employant des volumes importants d'eau à des fins industrielles. On conçoit donc que toute modification du bilan «eau douce-eau de mer», provoquée par la dérivation d'affluents, par la réalisation de chenaux de coupure, ou par d'importants ouvrages de régularisation dans l'estuaire, risque de perturber gravement les conditions biologiques et industrielles. Etant donné qu'il n'est guère possible, au stade actuel des connaissances, d'évaluer, de manière sûre, les conséquences de tels aménagements, les ingénieurs doivent, pour étudier le mélange des eaux douce et salée, avoir recours à des essais sur modèle réduits.

Des progrès considérables ont été réalisés, au cours des trente dernières années, dans les techniques expérimentales employées pour les études sur modèle. Grâce à des améliorations successives. apportées aux appareils de mesure, il est possible, aujourd'hui, de contrôler le fonctionnement des modèles avec une grande préci- sion, et ainsi d'en tirer davantage de renseignements utiles. Ces améliorations ont également permis de mettre en évidence certains défauts, dont l'existence n'avait pas été soupçonnée auparavant, et, dans bien des cas, de démontrer l'influence prépondérante de certains phénomènes, tels que les courants salins et courants de densité.

Des auteurs antérieurs $[1,2,3,4]$ ont décrit l'influence nette de la répartition de la salinité sur le schéma des courants de circulation dans un estuaire, mais ils ont tous tendu à ne souligner l'importance de cette répartition que pour le cas des estuaires, soit très nettement stratifiés, soit comportant des eaux seulement partiellement mélangées. Les auteurs de la présente étude cherchent à franchir une étape de plus, et à montrer pourquoi, même dans les estuaires dont lés eaux sont bien mélangées, il est parfois essentiel de considérer, avec une attention toute particulière, les courants salins et de densité. Ils examinent les difficultés pratiques de représenter, correctement, les répartitions horizontale et verticale de. la salinité, dans de tels modèles d'estuaires, et proposent des moyens permettant de résoudre ces difficultés, par l'application de techniques appropriées.

\section{INFLUENCE DE LA REPARTITION DE LA SALINITE DANS LES ESTUAIRES}

L'eau douce, pénétrant dans un estuaire, dilue l'eau de mer remontant et descendant l'estuaire sous l'influence des marées. Lor's du mélange des eaux douce et salée, il s'établit des répartitions de salinité horizontale et verticale. La figure 1 montre les répartitions longitudinales de la salinité, aux hautes eaux et aux basses eaux, dans l'estuaire de la Tamise, pour un débit moyen d'eau douce au droit de «Teddington Weir»(1).

Un observateur placé en $\ll \otimes$ constaterait, d'une part, une augmentation de la salinité pen-

(1) N.d.T. : Teddington Weil est un barrage déversant situé à la limite amont de la marée dans la Tamise, dans la banliene sud-ouest de Londres. dant le flux, la salinité maximale étant atteintc peu après les hautes eaux, et d'autre part, une baisse de la salinité pendant le reflux, la valeur minimale étant atteinte juste après les basses eaux. La dimension horizontale $\mathrm{BC}$ représente grosso modo le parcours de la marée dans cette partie de l'estuaire, c'est-à-dire la dislance parcourue à mi-marée, par un flotteur, on bien, plus précisément, la distance parcourue par le centre de gravité d'une masse d'eau injectée, soit en $B$, soit en $C$, pendant chaque reflux ou chaque flux. Vers l'aval, la différence entre les taux de salinité correspondant aux hautes et basses eaux diminuera progressivement, pour une station donnée, jusqu'au point (marqué X sur la figure 1) où la salinité corres- 
just after L.W. The horizontal dimension BC represents the approximate tidal excursion in this part of the estuary; i.e. the distance a float will travel per half-tide, or, more precisely, the distance travelled by the centre of gravity of a mass of water injected at $B$ or $C$ per ebb or: flood tide. Proceeding downstream the difference in salinity from H.W. to L.W. for a particular station will decrease until a point ( $\mathrm{X}$, Fig. 1) is reached where there will be no change in salinity from H.W. to L.W. The point $X$ and the distance $B C$ (which will vary with the shape of the estuary) have special significance for the model engineer, for he will normally be required to place his tide generator downstream of $\mathrm{X}$ by a distance equal to $\mathrm{BC}$. This subject is discussed in a later section of the note.

Salt water intrudes into the estuary as a wedge, the interface between the salt and fresh water varying from well-defined to almost obscure according to the degree of mixing that takes place. It is therefore convenient to classify estuaries by this criterion into:

a) Highly-stratified;

b) Partly-mixed;

c) Well-mixed.

(See Reference [2]).

The need to represent the salinity distribution in models of estuaries of types $a$ ) and $b$ ) is obvious, but in models of the Thames and Mersey, which are estuaries in the last category, it was also found to be necessary to reproduce the natural salinity distribution in order to obtain the correct velocity pattern.

M. R. Abbott in his paper" "Salinity effects in estuaries" (Ref. [5]) proposes a useful criterion to determine the relative importance of salinity/ density effects in an estuary. He suggests that a rough measure of the relative importance of salinity/density effects in a general estuary "... may be obtained from the dimensionless number.

$$
\mathrm{D}=\frac{c^{3}\left|\partial_{\rho} / \partial x\right|}{\omega \mathrm{U}_{0}^{2}{ }^{2}}
$$

$\mathrm{D}$ is proportional to the ratio of the density gradient term to the sum of the convective acceleration terms in the longitudinal equation of motion, ...".

Here :

$$
\begin{aligned}
c & =\sqrt{g h} ; \\
h & =\text { the mean depth; } \\
\hat{2} & =\text { water density } \\
\mathrm{U}_{0} & =\text { current amplitude. }
\end{aligned}
$$

"Small values of $D$ indicate that the most important second order effects are the nonlinear convective terms in the equation of motion, these giving rise to sizable drift currents in an estuary as shown by Abbott (1960). On the other hand, large values of D indicate that any drifts are due primarily to salinity differences. Examples are: Thames, $\mathrm{D}=0.8$; Mersey, $\mathrm{D}=7$; James, $\mathrm{D}=12$. Thus in the latter two estuaries, salinity effects predominate; this is confirmed numerically by Pritchard (1956), who has shown from observations in the James River (a tributary estuary of Chesapeake Bay) that the convective terms of mean motion are insignificant compared to the terms dependent on density gradient, surface slope and shear force."

"In calculating values of $\mathrm{D}$ above, the steepest

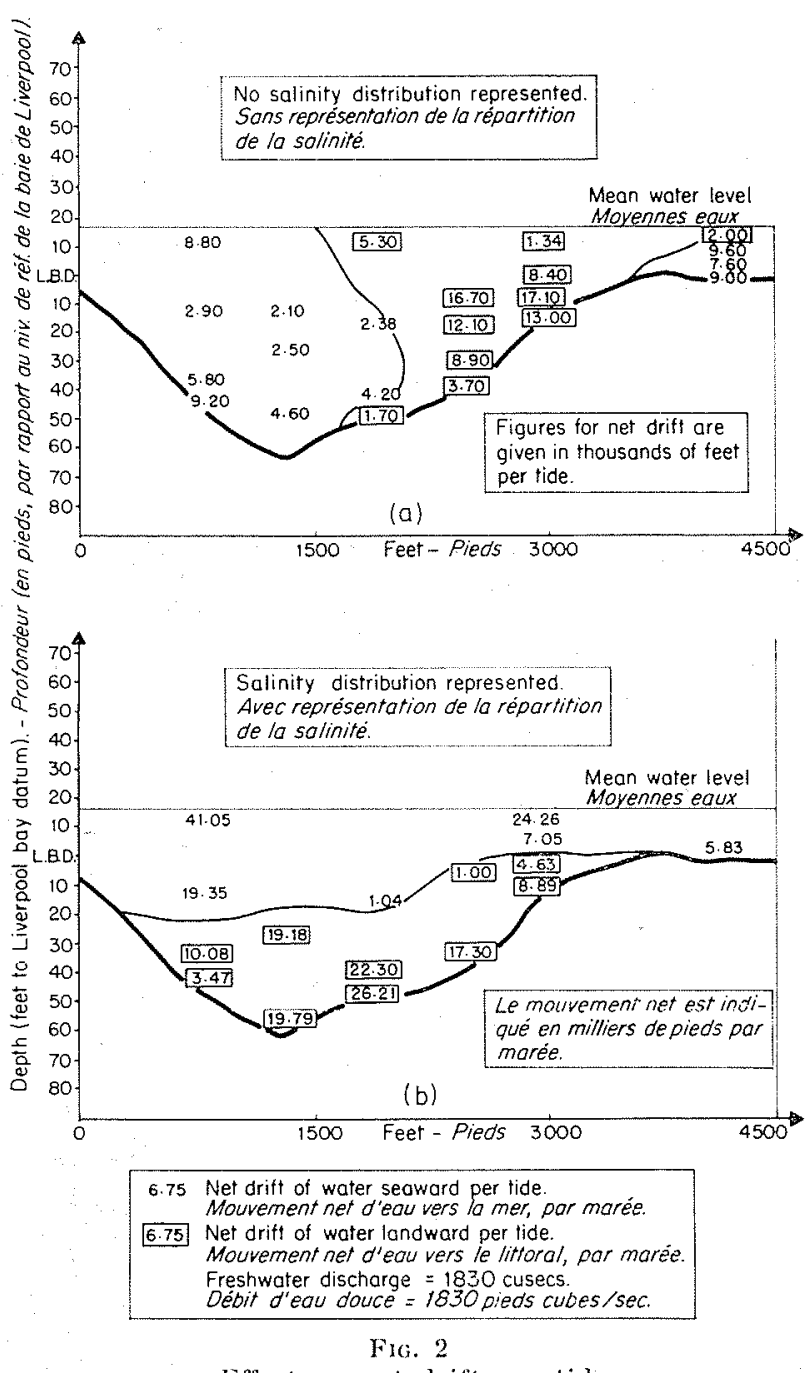

Effect on net drift per tide of representing prototype salinity distribution in model of Mersey estuary.

Influence sur le mouvement d'eau net, de lit représentation

de la répartition de salinité "nature» dans le modele de l'estuaire de la Mersey. 
pondant aux hautes eaux sera la mème que celle correspondant aux basses eaux. Le point $\mathrm{X}$, et la longueur $B C$ (qui varie avec la configuration de l'estuaire) sont tous les deux d'une importance particulière pour l'exploitant du modèle, qui devra normalement implanter son générateur de marée à une distance égale à $\mathrm{BC}$, en aval dudit point $X$. On reviendra sur ce point plus tard.

L'eau de mer pénètre dans l'estuaire sous la forme d'une langue salée, et l'interface séparant les eaux salées des eaux douces, sera plus ou moins nettement définie, ou même pratiquement méconnaissable, suivant l'intensité du brassage des eaux. Ce critère permet d'établir, pour les estuaires, la classification utile ci-dessous :

a) Estuaires très stratifiés;

b) Estuaires aux eaux partiellement mélangées;

c) Estuaires aux eaux bien mélangées.

[Voir réf. 2].

Il va de soi que la représentation de la salinité s'impose pour les modèles d'estuaires appartenant aux catégories $a$ et $b$; par contre, dans les modèles de la Tamise et de la Mersey, lesquels correspondent à la catégorie $c$, il s'est également révélé nécessaire de reproduire la répartition naturelle de la salinité, ceci afin de pouvoir déterminer la répartition précise des vitesses.

Dans son mémoire «Salinity effects in estuaries $\gg[5]$, M. R. Abbott propose un critere utile pour la détermination de l'importance relative des phénomènes de salinité et de densité dans un estuaire. D'après cet auteur, «il est possible d'obtenir une mesure approchée de l'importance relative des phénomènes de salinité et do densité, dans un estuaire de caractère général... à partir du nombre sans dimensions :

$$
\mathrm{D}=\frac{c^{3}\left|\partial_{0} / \partial x\right|}{\omega \mathbf{U}_{0}{ }^{2} ?}
$$

D étant proportionnel au rapport entre le terme désignant le gradient de densité, ef la somme des termes d'accélération de convection, dans l'équation longitudinale du mouvement..."

On a :

$$
\begin{aligned}
c & =\sqrt{g h} \\
h & =\text { profondeur d'eau noyenne; } \\
0 & =\text { densité de l'eau; } \\
\mathrm{U}_{0} & =\text { ampliude du courant. }
\end{aligned}
$$

Des faibles valeurs de D indiquent que les phénomènes du deuxième ordre les plus importants sont les termes non-linéaires de convection dans l'équation du mouvement, lesquels donnent naissance (ainsi que l'a démontré Abbott en 1960) à des courants de transport appréciables dans un estuaire. Par contre, des grandes valeurs de D indiquent que ces courants sont provoqués, surtout, par des différences de salinité. Par exemple pour la Tamise, $\mathrm{D}=0,8$; pour la Mersey, $\mathrm{D}=7$; pour l'estuaire de James River, $\mathrm{D}=12$. Ainsi, les phénomènes de salinité prédominent dans les deux derniers cas, ce qui a d'ailleurs été vérifié numériquement par Pritchard (1956), qui a démontré, sur la base de mesures effectuées dans la James River (laquelle se jette dans la baie de Chesapeake), que les termes du mouvement moyen sont insignifiants, en face de ceux dépendant du gradient de densité, de la pente superficielle, et de la force de cisaillement.

En calculant les valeurs de ce coefficient D, on tient compte du gradient de salinité le plus raide, pour l'estuaire considéré. Bien que les valeurs ainsi obtenues ne soient que des valeurs approchées, elles indiquent néanmoins l'importance relative des phénomènes de salinité dans chacun des trois estuaires.

On notera, cependant, que, même pour le modèle de l'estuaire de la Tamise, il s'est révélé nécessaire de reproduire la répartition de la salinité, afin de pouvoir obtenir le schéma correct des courants de circulation dans l'estuaire.

Dans le cas de l'estuaire de la Mersey, Abbott démontre, également, que sa théorie est valable pour la prédétermination de l'endroit, dans l'estuaire, où le mouvement, juste au-dessus des fonds, change de sens et ne se dirige plus vers le littoral, mais vers la mer. Le modèle de l'estuaire de la Mersey, réalisé à la Station des Recherches Hydrauliques de Wallingford, a permis de confirmer l'impossibilité de reproduire ce phénomène tant que l'on ne reproduisait pas la répartition de la salinité.

La différence maximale entre les taux de salinité au fond, et à la surface, n'étant que de l'ordre de $2 \%$, les eaux de l'estuaire de la Mersey peuvent être considérées comme étant bien mélangées; cependant, lorsque la répartition de la salinité n'a pas été représentée sur le modèle, les résultats ont été faussés. Cette constatation est d'ailleurs vérifiée par les deux schémas de la figure 2, lesquels ont été obtenus à partir de résultats de mesures continues de vitesses réparties dans une section située à quelque 7 ou $8 \mathrm{~km}$ à l'amont de l'entrée de l'estuaire de la Mersey. En mesurant l'aire délimitée, à sa partie supérieure, par la courbe des vitesses en fonction du 
salinity gradient in an estuary is used; though the values given are only rough, they give an indication of the relative importance of salinity effects in the three estuaries."

It should be noted however that even in the model of the Thames estuary it was necessary to reproduce the salinity distribution in order to obtain the correct estuarine circulation pattern.

In the case of the Mersey estuary Abbott also shows that his theory can be used to predict the position in the estuary at which the drift just above the bed reverses from landward to seaward. The model of the Mersey estuary constructed at the Hydraulics Research Station, Wallingford confirmed that this effect could not be simulated without the reproduction of the salinity distribution.

The maximum difference in salinity between bed and surface water is only of the order of 2 p.p.th. indicating that the Mersey is a wellmixed estuary, yet failure to reproduce the salinity distribution in the model gave misleading results. This fact is further illustrated by the two diagrams in Figure 2 which are deriyed from the results of continuous velocity measurements taken across a section about 5 miles upstream of the entrance to the Mersey estuary. An estimate of the drift of water past each point on the section per flood or ebb tide can be obtained by measuring the area under the curve of velocity versus time. (See Ref. [6]) The difference between the two areas represents the net drift of water per tide past the particular point on the section; thus by observing a number of points a picture of the distribution of flow across the whole section may be built up. The figures in both diagrams in Figure 2 are given in thousands of feet per tide, the upper diagram indicating that when the model is operated entirely with fresh water there is a net landward drift of water at all depths in the centre of the channel, compensated by a net seaward drift at the sides. In the lower diagram however, which shows the results obtained when the correct longitudinal and vertical salinity distributions are reproduced in the model, a net landward drift of water occurs at all stations near the bed whilst a net seaward drift is confined to the surface layers.

Thus, in an investigation such as that of the Mersey where it is necessary to reproduce the mechanism by which relatively coarse material is transported from one area to another, it would be incorrect to operate the model without first simulating the prototype salinity distribution. Assuming that, for the most part, material moves in the same direction as the water, then the results would vary considerably depending on whether model operation was as depicted in Figure $2 a$ or $2 b$. This in fact proved to be the case in the Mersey model, sand being transported downstream to accumulate in the entrance chamnel whenever the salinity distribution was incorrectly represented, instead of travelling upstream to deposit in the upper estuary.

\section{SALINITY CONTROL IN ESTUARY MODELS}

In the linear, velocity and time seales for a model are selected according to the Froude relationships, and it is proposed to represent the salinity/density effects by the introduction of sodium chloride, then it is normally satisfactory to choose a salinity scale of $1 / 1$. It is only when the viscous effects become predominant, as in the case of a highly-stratified estuary where the salt wedge travels a relatively long distance, that such a combination of scales leads to incorrect results. This subject is examined in some detail by Keulegan in his Progress Reports on Model Laws for Density Currents. (Reference [7]).

During a tidal cycle a volume of fresh-water equal to the volume introduced by fresh-water tributaries, must in the same period of time move seaward through each section of the model. Furthermore there must be no net exchange of salt across a section during a tidal cycle. This, of course, does not mean that the circulation of salt water is zero at all points on the section, but that there is a balance between the inflow and outflow of sea water over the section as a whole. Clearly the water entering a model estuary from tributaries and streams must be discharged to waste at the seaward end of the model. This waste will be associated with a certain amount of salt so that concentrated brine will have to be added at the seaward end to make up for the loss. In short there must be no gain to or loss from the system of either salt or water.

The method of salinity control successfully used in both the Thames and Mersey models is shown diagrammatically in Fig. 3.

Let $W_{1}=$ the weight of fresh water added to the model from tributaries (lb/min); 
temps, on peut évaluer le mouvement de l'eau, au droit de chaque point de la section, pour chaque flux ou reflux [6]. La différence entre les aires des deux schémas représente le mouvement d'eau net, pour chaque marée, au droit du point considéré de la section; ainsi, en observant plusieurs points différents, on peut se faire une idée de la répartition de l'écoulement dans l'ensemble de la section.

Dans le schéma de la figure 2 , les valeurs sont exprimées en milliers de pieds par marée; d'après le premier schéma, lorsque le modèle coule seulement avec de l'ean douce, il se produit, à toutes profondeurs au centre du chenal, un mouvement net vers le littoral, compensé, de part et d'autre, par des mouvements nets vers la mer. Par contre, dans le deuxième schéma représentant les résultats obtenus en tenant compte correctement, sur le modèle, des répartitions longitudinale et verticale de la salinité, on constate, en toutes stations au voisinage du fond, l'existence d'un mouvement net, vers le littoral, alors que le mouvement net vers la mer ne se produit que dans les couches superficielles.

Ainsi, pour une étude telle que celle de la Mersey (où il est nécessaire de représenter le processus provoquant le transport des matériaux relativement grossiers, d'une zone à l'autre) aucun essai sur le modèle ne serait valable tant que l'on n'y aurait pas, au préalable, reproduit la répartition réelle de la salinité. Dans l'hypothèse d'un transport de la plupart des matériaux, dirigé dans le même sens que le mouvement de l'eau, des résultats très différents seraient obtenus, suivant que le modèle fonctionnerait dans les conditions de la figure $2 a$, ou dans celles de la figure $2 b$. C'est en effet, ce qui s'est passé pour le modele de la Mersey; chaque fois que la répartition de la salinité était mal représentée, le sable se trouvait transporté vers l'aval, et se déposait dans le chenal d'accès, au lieu de remonter vers l'amont, et de se déposer ensuite dans la partie supérieure de l'estuaire.

\section{LE RÉGLAGE DE LA SALINITÉ DANS LES MODĖLES D'ESTUAIRE}

Lorsque les échelles de vitesse et de temps d'un modele sont choisies en fonction de la similitude de Froude, et lorsque les phénomènes de salinité et de densité sont reproduits par l'introduction de chlorure de sodium, une échelle de salinité de 1/1 permet, normalement, d'obtenir des résultats valables. Ce n'est que lorsque les phénomènes visqueux prédominent (comme dans le cas d'un estuaire très stratifié, dans lequel la langue salée parcourt une distance relativement importante), qu'une telle combinaison d'échelles conduit à des résultats erronés. Cette

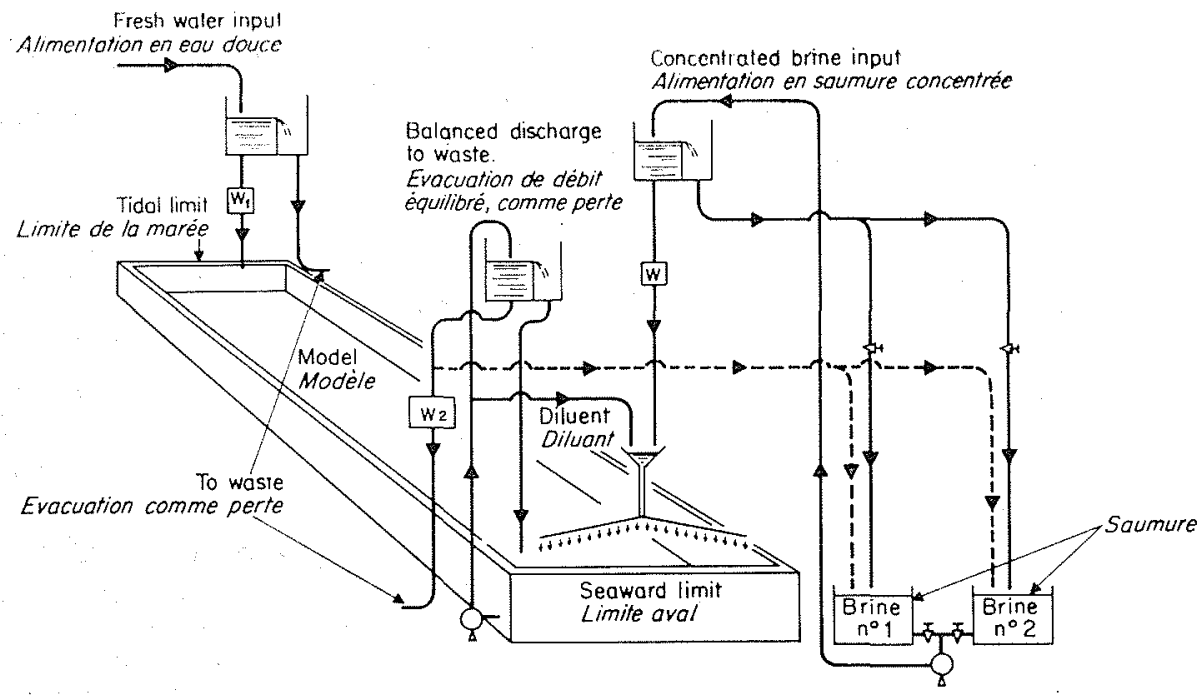

Fic. 3

biagram showing method of salt injection to an estuary model.

Schéma d'une installation d'injection saline pour un modèle d'estuaire. 
Let $w=$ the weight of water added to the model as a part of the concentrated brine (lb/min);

Let $S_{1}=$ weight of salt added to the model in the concentrated brine ( $\mathrm{lb} / \mathrm{min})$;

Let $\mathrm{W}_{2}=$ weight of water discharged to waste (lb/min);

Let $\mathrm{S}_{2}=$ weight of salt discharged to waste (lb $/$ min).

Having decided on the strength of the concentrated brine, the ratio of $w: \mathrm{S}$, is known. The salinity at the seaward end of the model is at sea strength so that the ratio of $\mathrm{W}_{2}: \mathrm{S}_{2}$ is also known. Sodium chloride (common salt), which is normally used, forms a saturated solution at a strength of 250 p.p.th by weight at normal room temperature, but at concentrations approaching this level it becomes difficult to dissolve. A strength of 200 p.p.th has been found to be convenient for all practical purposes and this concentration has been assumed in the calculations made below.

If it is postulated that the water discharged to waste contains 34 p.p.th by weight of salt (sea strength) then:

$$
\begin{aligned}
W_{1}+w & =W_{2} \ldots \ldots \ldots \ldots \ldots \ldots \\
S_{1} & =S_{2} \ldots \ldots \ldots \ldots \ldots \ldots \\
\frac{W_{1}}{S_{1}}=\frac{800}{200} & =4 \ldots \ldots \ldots \ldots \\
\frac{W_{2}}{S_{2}} & =\frac{966}{34} \ldots \ldots \ldots \ldots
\end{aligned}
$$

It will be seen from these equations that the wastage of salt will be a minimum when the strength of the concentrated brine is a maximum. In fact if it were found practicable to add dry salt there would be minimum wastage. From the four equations above it is possible to calculate the quantity of salt required, the amount of concentrated brine to be added to the model and the amount of water at sea strength to be discharged to waste.

A diagrammatic sketch of a simple method of continuous control used in reproducing the salinity distribution in an estuary model is shorwn in Figure 3. It is designed for a set value of fresh-water flow, which is normally adequate for most model studies. However a control system is under development at the Hydraulics Research Station, Wallingford which will feed a fresh-water hydrograph into the model and automatically compensate the brine and waste flows. In this system a voltage analogue of the required pattern of fresh-water discharge is passed through electronic circuits, which produce voltages representing the required instantaneous flow of brine and waste. The three voltages are applied as input signals to flow controllers in the respective pipes.

To establish the correct salinity distribution in a model normally takes some considerable time (Fig. 4), and in order to avoid this initial period of settling down whenever the model is switehed on, it is more efficient to operate for several days, and sometimes even several weeks, at a time. It is thus particularly important that there should be no variation in the quantities of salt and water in the system as this could afiect tidal generation. For example, where plunger-type tide generators are installed the correct H.W. and L.W. levels in the model are a function of the amount of water in the system. In the case of electronically-controlled tide generators, however, the tide curves reproduced at the tidal limit are, up to a point, independent of the amount of water in the system, but even here a continuous gain or loss of water over

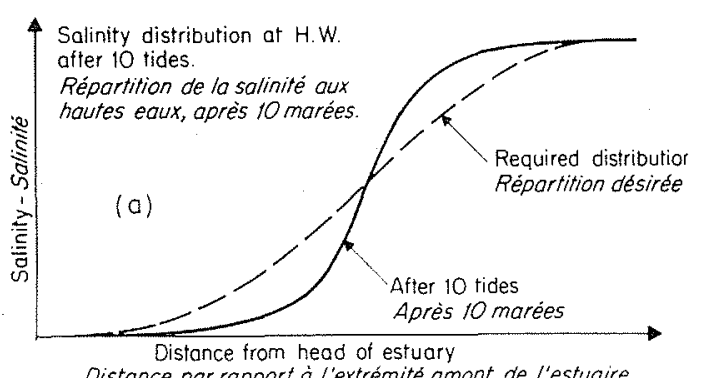

Distance par rapport $\dot{a}$ /'extrémité amont de l'estuaire
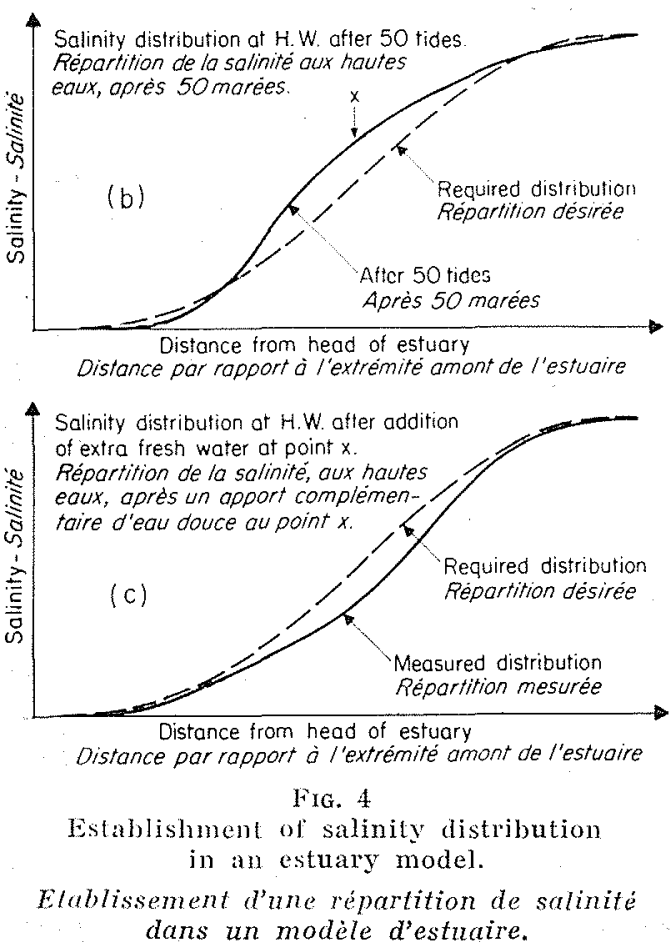
question a été examinée d'une manière assez détaillée par Keulegan ( Progress Reports on Models Laws for Density Currents ») [7].

Au cours d'un cycle de marée, il doit s'écouler vers la mer, par chaque section du modèle, un volume d'eau douce égal à l'apport, dans l'estuaire, des affluents d'eau douce pendant le mème temps. Par ailleurs, aucun échange net de sel ne doit avoir lieu, dans une section, au cours d'un cycle de marée. Ceci ne veut pas dire, bien entendu, que la eirculation d'eau salée est nulle en tous points de la section, mais signifie qu'il s'établit un équilibre entre les débits d'eau de mer arrivant et sortant, sur l'ensemble de la section. Il est évident que l'eau apportée à un modèle d'estuaire par des affluents et des cours d'eau, doit être évacuée en pure perte à l'extrémité aval du modèle; et puisque cette évacuation entraîne une certaine quantité de sel, il est nécessaire de faire l'appoint par de la saumure fortement concentrée, à cette extrémité aval, afin de compenser cette perte. En résumé, les quantités d'eau et de sel dans un modèle ne doivent ni augmenter, ni diminuer.

L’installation de réglage de la salinité qui a été employée avec succès pour les modèles de la Tamise et de la Mersey, est représentée schématiquement sur la figure 3 , dans laquelle :

$W_{1}=$ l'apport (en poids) d'eau douce des affluents au modèle (en livres/minute);

$w=$ l'apport (en poids) d'eau correspondant à la partie aqueuse de la saumure concentrée (en livres/minute);

$S_{1}=$ l'apport (en poids) de sel, correspondant à la partie saline de la saumure concentrée (en livres/minute);

$W_{2}=$ le débit d'eau (en poids) évacué en pure perte (en livres/minute);

$\mathrm{S}_{2}=$ le poids de sel évacué en pure perte (en livres/minute).

Ayant choisi la concentration de la saumure à amener au modèle, on connaît la valeur du rapport $w: \mathrm{S}$. Puisque les taux de salinité, à l'extrémité aval du modèle, correspond à celui de l'eau de mer, on connaît également la valeur du rapport $W_{2}: S_{2}$. Le chlorure de sodium (sel ordinaire) que l'on emploie normalement à cette fin, donne, à la température ambiante, une solution saturée concentrée à $25 \%$ (en poids), mais ce sel se dissout difficilement aux concentrations approchant cette valeur. Un taux de concentration de $20 \%$ s'est montré suffisant pour toutes fins pratiques, et c'est cette valeur qui a été admise dans les calculs qui suivent.

Admettons, pour l'eau évacuée en pure perte, une teneur en sel (en poids) de $34 \%$, correspondant au taux de salinité de l'eau de mer. Nous avons :

$$
\begin{aligned}
W_{1}+w & =W_{2} \ldots \ldots \ldots \ldots \ldots \ldots \\
\mathrm{S}_{1} & =\mathrm{S}_{2} \ldots \ldots \ldots \ldots \ldots \ldots \ldots \\
\frac{W_{1}}{\mathrm{~S}_{1}}=\frac{800}{200} & =4 \ldots \ldots \ldots \ldots \ldots \ldots \ldots \ldots \ldots
\end{aligned}
$$

Ces équations montrent que la perte en sel est minimale lorsque le taux de concentration de la saumure est maximal. D'ailleurs si, pratiquement, il était possible d'ajouter du sel sans eau, la perte serait encore plus faible. Les quatre équations précédentes permettent de calculer, à la fois, la quantité de sel nécessaire, l'apport de saumure concentrée à prévoir, et le débit d'eau salée à la concentration de l'eau de mer à évacuer en pure perte.

La figure 3 représente le schéma simplifié du dispositif de réglage continu employé pour représonter la répartition de la salinité dans un modèle d'estuaire. Ce dispositif a èté concu pour une seule valeur du débit d'eau donce, ce quil suffit pour la plupart des études sur modèle. Cependant, la Station de Recherches Hydrauliques de Wallingford met actuellement au point un dispositif de réglage, qui introduira l'eau douce dans le modèle en fonction d'un hydrogramme pré-déterminé, et qui compensera, automatiquement, Jes débits de saumure et d'évacuation en pure perte. Son principe de fonctionnement est le suivant : on fait passer une tension électrique en analogie avec le schéma désiré des débils d'eau douce, à travers des circuits électroniques, lesquels engendrent des tensions représentant les débits instantanés désirés de la saumure et de l'évacuation en pure perte. Ces trois tensions agissent, sous forme d'impulsions, sur des appareils de réglage des débits, disposés dans les tuyaux correspondants.

L'établissement de la répartition correcte de la salinité dans un modèle prend normalement beaucoup de temps (fig. 4); afin d'éviter cette période de stabilisation initiale lors de chaque mise en route du modèle, il est plus judicieux de le laisser conler pendant plusieurs journées, voire plusieurs semaines, sans arrêt. En effet, il est essentiel d'éviter toute variation des quanlités de sel et d'eau présentes dans le circuit, Jaquelle serait capable de fausser la reproduc- 
long periods might become embarrassing. It is stressed, therefore, that it is important to control accurately the amounts of fresh and salt water added and substracted. If the flows are not too large then the best method is to discharge through a sharp-edged orifice at a constant head, the head being maintained by an overflow weir in the form of a funnel connected to the bottom of the tank by a flexible hose. By adjusting the height of the funnel the head can be varied slightly to give the required discharges. It is worth mentioning, because mistakes are often made through over-familiarity with the orifice equation, that when calculating the head required to discharge given quantities of brine and water at sea strength due allowance must be made for the density of the fluid.

The specific gravity of concentrated brine at 200 p.p.th is 1.148 at $20^{\circ} \mathrm{C}$, and if this were to be added to the model directly it would sink to the bed and flow upstream as an extremely dense wedge, changing the current velocity pat- tern considerably. It is, therefore, essential to mix the brine with a quantity of recirculated water at sea strength from the seaward end of the model. In Figure 3 this has been done by by-passing water from the pump discharging water to waste.

If small quantities of brine are required, then the easiest method of preparation is to support wicker baskets - lined with muslin - in the surface layers of a tank of water. In dissolving, the salt in the baskets sets up a density circulation in the tank which assists in the solution of more salt. An occasional stir with a paddle will also help the process. If large quantities of brine are required then it might be necessary to mix the salt automatically in a system such as that shown in Figure 5 where the pump circulating the brine is switched off automatically when the correct strength has been reached. The prepared brine is then pumped into a reservoir tank for use in the model.

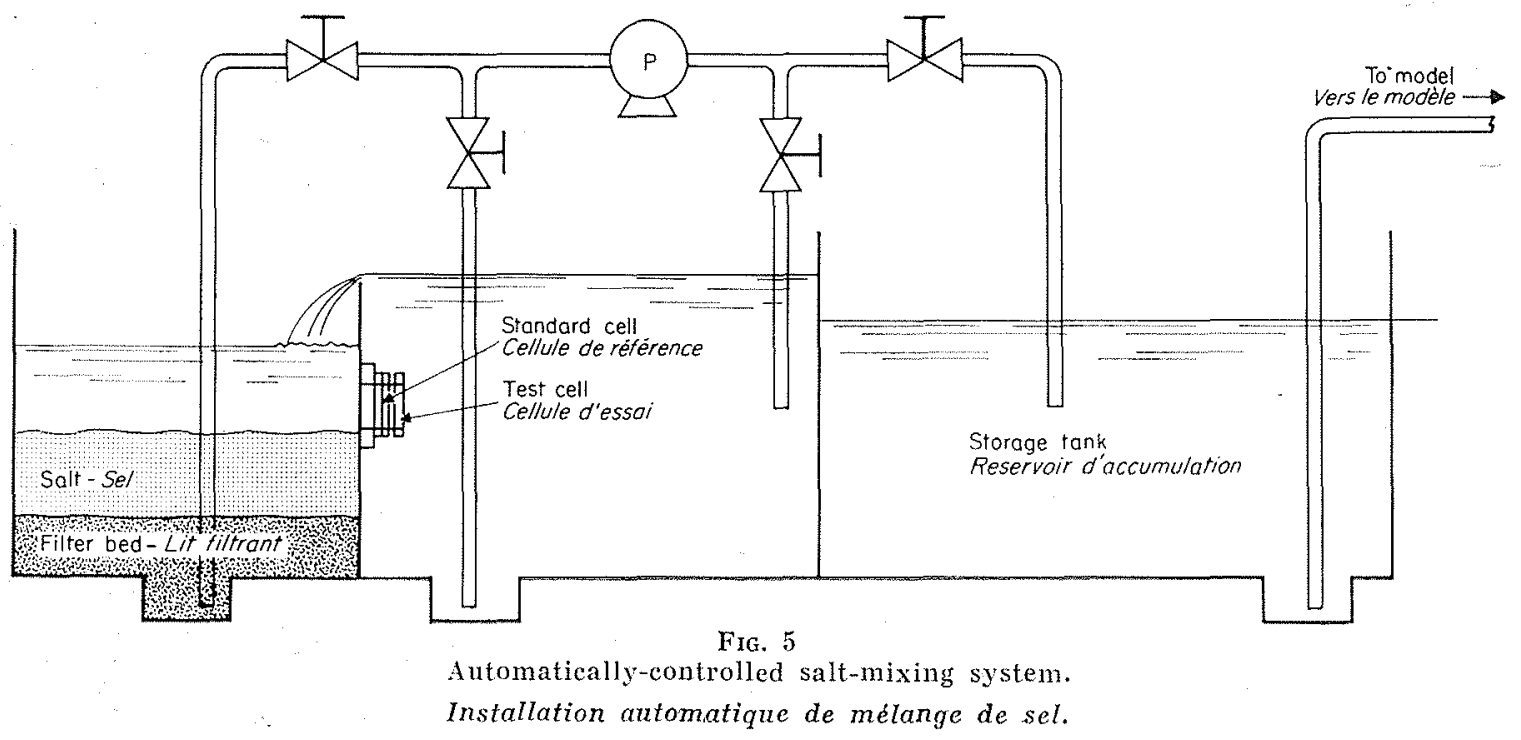

\section{OPERATION OF ESTUARY MODELS}

Reproduction of the prototype vertical and longitudinal salinity distribution is not achieved merely by adding the required amount of fresh water to the model and by adding and subtracting the calculated quantities of brine and water at sea strength. This only ensures that the end conditions of the model are correct. The general hydraulic characteristics, the most important of these being the mixing, must also be correct. Failure to reproduce the right salinity distribution in a model is normally due to too little mixing, and this can be corrected, at least in fixed-bed models, by inserting perforated metal on the bed. Where salinity/density effects are likely to be significant it is well worth spending the time faithfully proving the model from the point of view of tidal propagation before making any salinity/density studies, because it is found that if the tides are right then the salinity distribution is almost certain to be correct. In fact, the most sensitive indication of good tidal reproduction has been found to be good salinity reproduction both horizontally and vertically.

Having made all the necessary calculations and installed the necessary apparatus we now require a procedure for starting up the model. 
tion des marées. Par exemple, dans le cas des générateurs de marée du type «à piston», les niveaux d'eau maximal et minimal corrects, dans le modèle, sont fonction de la quantité d'eau contenue dans le circuit. Par contre, dans le cas des générateurs à commande électronique, les courbes de marée reproduites à la limite de la marée sont, dans une certaine mesure, indépendantes de cette quantité d'eau; cependant, même dans ce cas, tout gain ou toute perte d'eau, continus et de durée prolongée, risqueraient de devenir gênants. Il est donc très important d'assurer le réglage précis des quantités d'eau douce et d'eau salée apportées au modèle ou soustraites à celui-ci. Pour cela, et à condition que les débits ne soient pas trop élevés, la meilleure méthode consiste à évacuer le débit à travers un diaphragme à arêtes vives, fonctionnant sous une charge constante assurée par un déversoir en entonnoir relié au fond du réservoir par un tuyau souple. En jouant sur le calage en altitude de ce déversoir, on fait varier légèrement la charge, ce qui permet de régler le débit à la valeur voulue.

Enfin, notons que la loi de l'écoulement par un diaphragme est si bien connue qu'elle tend parfois à ètre appliquée avec une certaine négligence conduisant souvent à des erreurs; il paraît done bon de rappeler qu'en calculant la charge correspondant à des débits bien déterminés de saumure, et d'eau salée à la concentration de l'eau de mer, on doit tenir compte de la densité du fluide.

La densité de la sammure concentrée à $20 \%$, est de 1,148 , à la température de $20^{\circ} \mathrm{C}$. Or, si l'on introduisait une telle saumure directement dans le modèle, elle irait directement au fond, et remonterait ensuite vers l'amont sous la forme d'une langue salée extrêmement dense, ce qui modifierait considérablement le schéma des vitesses des courants. Il est donc essentiel, d'abord, de diluer cette saumure dans une certaine quantité d'eau de recirculation ayant la concentration de l'eau de mer, et provenant de l'extrémité aval du modèle. Le schéma de la figure 3 montre comment ce mélange a été réalisé, au moven d'un piquage sur la pompe d'évacuation d'eau en pure perte à l'aval.

Pour les cas ne nécessitant que de faibles quantités de saumure, le mélange se réalise, le plus aisément, en installant dans les couches superficielles d'un volume d'eau contenu dans un bac, des paniers en osier, garnis de mousseline, et contenant du sel; la dissolution de ce sel donne naissance, à l'intérieur du bac, à une circulation de courants de densité laquelle fait, à son tour, dissoudre encore du sel. On peut, par ailleurs, accélérer cette dissolution du sel en remuant le mélange de temps en temps à la main. Par contre, dans les cas exigeant de fortes quantités de saumure, il faudrait éventuellement prévoir une installation de brassage automatique, telle que celle représentée sur la figure 5 , dans laquelle la pompe de recyclage de la saumure s'arrête d'elle-même dès que la concontration voulue est atteinte. La pompe refoule alors la saumure ainsi préparée dans un réservoir d'alimentation du modèle.

\section{FONCTIONNEMENT DES MODELLES D'ESTUAIRE}

Il ne suffit pas, pour représenter la répartition réelle des salinités verticale et longitudinale, d'introduire tout bonnement dans le modèle la quantité d'eau douce voulue, et d'ajouter ou de soustraire les quantités calculées de saumure et d'eau salée à la concentration de l'eau de mer. Ceci assurerait seulement une représentation correcte des conditions aux extrémités du modèle; or il est nécessaire, également, que les caractéristiques hydrauliques (dont la plus importante est le processus de brassage) soient correctes. Les mauvaises représentations, dans un modèle, de la répartition de la salinité sont dues, pour la plupart, à un brassage insuffisant du mélange; cette difficulté peut être résolue (du moins dans les modèles à fond fixe) en prévoyant une tôle perforće sur le fond du modèle.
Lorsque l'influence des phénomènes de densité ou de salinité, est susceptible d'être déterminante, cela vaut toujours la peine de prendre tout le temps nécessaire pour assurer le réglage précis du modèle (du point de vue de la propagation de la marée), avant d'entreprendre des études quelconques de la salinité ou de la densité. En effet, l'expérience a montré, le plus souvent qu'il suffit que les marées soient reproduites fidèlement, pour que la salinité le soit aussi, presque certainement. En fait, la fidélité de représentation des salinités horizontale et verticale constitue le «baromètre » le plus sensible qu'il soit, quant à la fidélité de reproduction des marées.

Tous calculs faits, et tous les appareils ayant été installés, il s'agit, ensuite, de mettre le 
It is assumed that the model is fitted with a weir-type tide generator which has a sump large enough to accommodate a volume of water slightly greater than the tidal prism of the model. The best procedure is to drain the model to a level slightly below I..W. and arrange for water of sea strength to be mixed in the sump. As this stage tides may be generated and the automatic salinity control switched on. After, say, 10 tides the salinity distribution in the model will be as shown in Figure $4 a$. The greater the number of tides generated, the nearer the approach to the correct salinity distribution, but in order to save time it is sometimes advisable to speed up this process. Suppose the stage depicted in Figure $4 b$ has been reached at which the salinity in the middle of the estuary is too high. This could be lowered by the introduction of a fresh-water hose at point $X$, which, after running for a given time would lead to the curve shown in Figure $4 \mathrm{c}$. If the hose is switched off at this stage then it will not be long before the correct salinity distribution is established.

\section{APPLICATION OF THE ELECTRO-DIALYSIS PROCESS}

One of the main objections to producing the salinity distribution in a model by the method described is the considerable wastage of salt that takes place. In addition it might be found difficult to dispose of the salt water, especially into fresh-water streams where fish might be affected. Some method of recovering the salt would therefore be advantageous although normal evaporation recovery processes are clearly too expensive for hydraulic laboratories.

The electro-dialysis process, which was developed to enable drinking water to be obtained from brackish sources in areas poor in freshwater supplies, provides the hydraulic model engineer with new possibilities for the future. Although the capital cost of the equipment at the present time is too high, this should not continue to be the case once the system has been fully developed.
The principle behind the process is as follows. When an electro-potential is applied to electrodes immersed in a bath of sodium chloride the sodium ions move towards the cathode and the chlorine ions move towards the anode (See Fig. 6 and Ref. [8]).

Recently membranes have been produced which are impermeable to chlorine ions but permeable to sodium ions, whilst others are permeable to chlorine ions but impermeable to sodium ions. If such membranes are placed alternately between the electrodes (Fig. 6) a concentration of sodium and chlorine ions in compartments 2, 4, 6 , and 8 and a loss of both sodium and chlorine ions from compartments 3,5 and 7 will result. The concentration of salt will therefore increase in compartments 2, 4, 6, and 8 and decrease in compartments 3,5 and 7 . If such a unit could be produced at an economic cost, a reasonable

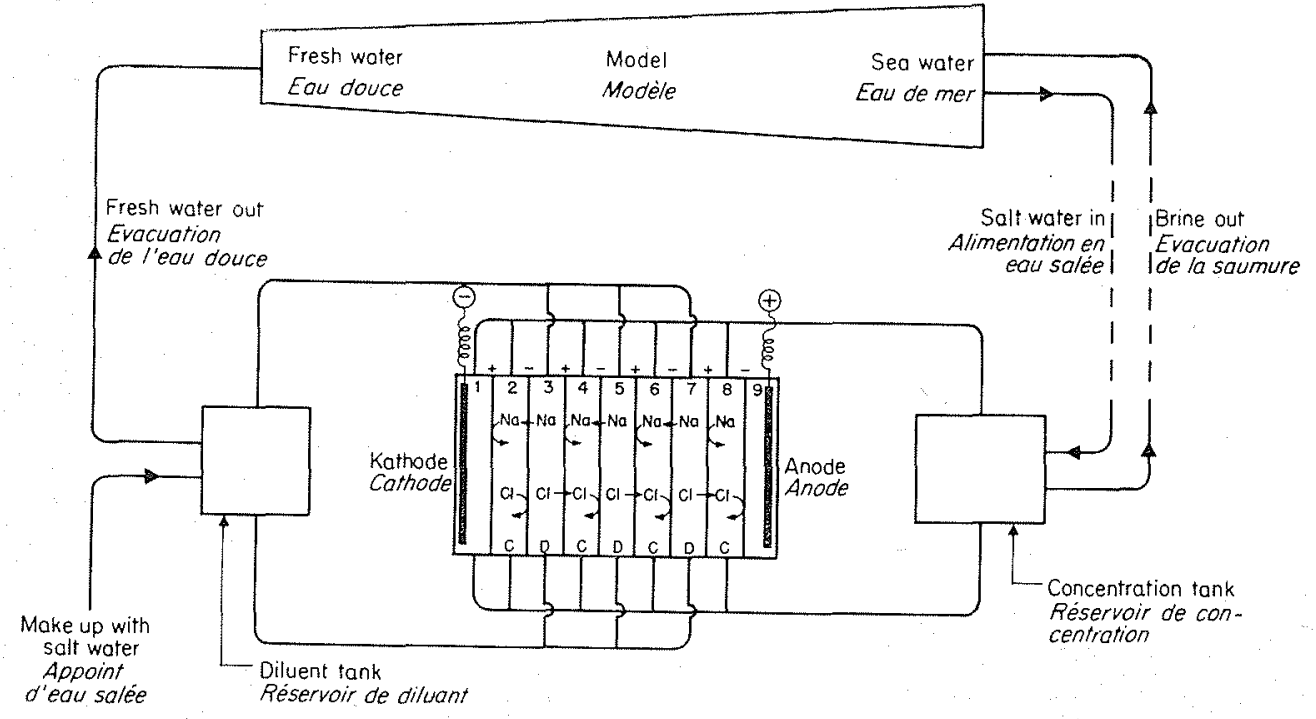

Fig. 6

Electrondialysis unit.

Installation électrodialytique. 
modèle en marche dans les meilleures conditions possibles. Admettons que le générateur de marées soit du type à déversoir, et qu'il comporte un réservoir suffisamment volumineux pour pouvoir contenir une quantité d'eau légèrement supérieure au volume de marée du modèle. La meilleure marche à suivre consiste alors à vider le modèle jusqu'à ce que le plan d'eau tombe légèrement au-dessous du niveau des basses eaux, et d'établir, dans le réservir, une concentration saline égale à celle de l'eau de mer. La génération des marées peut commencer à ce moment, ef l'on mettra en marche l'appareil automatique de réglage du taux de salinité. Après une dizaine de marées, la répartition de la salinité, dans le modèle, conespondra à celle représentée sur la figure $4 a$. Plus les ma- rées reproduites seront nombreuses, plus les répartitions de salinité «modèle se rapprocheront de la répartition «nature»; toutefois, il sera parfois nécessaire, afin de gagner du temps, d'accélérer cette évolution.

Admettons maintenant, que les conditions représentées sur la figure $4 b$ aient été atteintes, c'est-à-dire avec un taux de salinité excessif dans la partie centrale de l'estuaire. On pourrait réduire cotte concentration, en amenant de l'eau donce, au moyen d'un tuyau souple, en «X», de manière qu'au bout d'un certain temps, la courbe présente l'allure de celle de la figure $4 c$. Si, à ce moment, on arrètait celte alimentation en eau douce, la répartition correcte de la salinité ne tarderait guère à s'établir.

\section{EMPLOI DE LA MÉTHODE ELECTRODIALYTIQUE}

Un des principaux inconvénients de la méthode précédente est qu'elle entraîne un gaspillage de sel considérable. Par ailleurs, lévacuation d'eaux fortement chargées en sel peut présenter des difficultés, surtout lorsqu'elle se fait dans des cours d'eau naturels dans lesquels la salinité pourrait nuire aux poissons. Tout moyen permettant de récupérer ce sel serait certes intéressant, mais les procédés classiques par évaporation seraient évidemment trop coùteux pour que l'on puisse en envisager l'emploi dans un laboratoire d'hydraulique.

La méthode électrodialytique, qui fut élaborée en premier lieu pour permettre, dans les régions manquant de ressourcës naturelles en eau douce, d'obtenir cette eau à partir de sources saumâtres, présente de nouvelles possibilités pour l'ingénieur hydraulicien. Les appareils nécessaires sont actuellement encore trop chers, mais deviendront sans doute plus abordables une fois que la méthode sera bien au point. Son principe est le suivant:

L'application d'un potentiel électrique à des électrodes plongeant dans un bain de chlorure de sodium, provoque la migration, d'une part, des ions de sodium vers la cathode, et d'autre part, celle des ions de chlore vers l'anode (voir fig. 6 , et réf. [8]). On a récemment mis au point des membranes imperméables aux ions de sodium, et d'autres, imperméables aux ions de chlore. La disposition d'une sćrie alternante de telles membranes, entre les électrodes, permet d'obtenir, à la fois, une concentration des ions de chlore et de sodium dans les compartiments $2,4,6$, et 8 , et une baisse de la teneur en ces ions dans les compartiments 3 , 5 , et 7 . La concentration saline augmente donc dans 2, 4, 6 et 8 , et diminue dans 3,5 et 7 .

S'il était possible de réaliser économiquement un tel dispositif (hypothèse fort raisonnable, au surplus), cela permettrait de régler les taux de salinité, aux deux extrémités du modèle, aux valeurs voulues, ceci avec une perte de scl pratiquement nulle. En résumé, les avantages d'une telle installation seraient les suivants :

1. Le débit d'eau introduit en tête de l'estuaire pourrait être choisi et «programmé» à volonté, et la quantité de sel récupérée et restituée à la limite aval du modèle, varierait en fonction de ce débit.

2. Les pertes de sel seraient réduites au minimum.

Le fonctionnement d'une telle installation est représenté schématiquement par la figure 6 . 
enough supposition, then it would be possible to control the salinity at both ends of the model with practically no salt wastage. In short, the advantages of such a system would be that:

(i) the quantity of water supplied to the head of the estuary could be varied and programmed at will, the amount of recovered salt passing back to the seaward limit varying accordingly;

(ii) the wastage of salt would be reduced to a minimum.

The way in which such a system would operate is shown diagrammatically in Figure 6.

\section{METHODS OF MEASURING SALINITY}

In order to check the performance of the model from the point of view of salinity, it is necessary to compare the longitudinal salinity distribution with that for the prototype. The vertical salinity distribution is equally important and this must also be checked by sampling at surface, mid-depth and close to the bed at a number of points during the tidal cycle. The sampling is best done through a glass tube graduated with the prototype scale and connected to a rubber ball into which the sample is drawn. The most accurate way of analysing the samples is by the Knudsen titration method (Ref. [9]).

$$
\mathrm{AgNo}_{3}+\mathrm{NaCl}=\mathrm{AgCl}+\mathrm{NaNO}_{3}
$$

However, this is time-consuming and expensive in labour when large numbers of samples have to be analysed. A quick and fairly accurate method is to use a conductivity bridge which is a standard piece of commercial equipment. This instrument, which operates on the principle of a Wheatstone bridge, can be used to determine the conductivity of the sample in two ways. By the first method a direct reading of conductivity is obtained so that the salinity can be determined if the temperature is known. In the second method, which is considered to be more accurate, the sample is compared with a standard of known strength. Note that the sample and the standard have to be at the same temperature, but this can easily be arranged by standing the test-tube containing the standard in the water of the model. It is suggested that, to obtain maximum accuracy, the instrument be used over the central part of the scale, and it is found that solutions containing $5,10,15,20$ and 30 p.p.th of salt in $1,000 \mathrm{gms}$ of solution should be made up and used as standards: accuracies of $t 0.1$ p.p.th can be achieved in this way. It should be remembered that the fresh water flow introduced to the model normally comes from the nearest town water supply and will therefore contain some dissolved salts, the type and quantity varying according to the locality. It will thus be seen that the standard salinity samples to be used with the conductivity bridge must be made up with this water and not with distilled water.

The normal requirement in a salinity model is that the density effect should be correct. This is mentioned because in certain investigations where, say, the water in fresh-water tributaries was much warmer or colder than the sea, ther it would be necessary to make a correction in the salinity distribution by way of compensation. It is unlikely that this situation would arise in many investigations but it should be borne in mind, a difference in temperature of $5 \%$ being approximately equivalent to a salinity difference of 1 p.p.th.

\section{SIMULATION OF DENSITY CURRENTS BY STABLE CLAY SUSPENSIONS}

The main disadvantage of using salt water as a means of representing density currents in models is that it is highly corrosive. Even apparatus situated 20 to $30 \mathrm{ft}$ from the model becomes corroded, and instruments used on the models, which are necessarily delicate pieces of equipment, in turn suffer the same fate. Thus particular care should be taken over the choice of metals to be used in the construction of instruments and tide generators destined to be installed on salt-water models.
Other ways of reproducing density currents have therefore been explored - in particular the possibility of replacing the salt by stable clay suspensions. Most of the work on this subject (Ref. [10]) has been carried out by the Waterloopkunding Iaboratorium at Delft in Holland - understandably so, as Delft is situated in a region lying below sea level where the discharge of saline water from hydraulic models into the neighbouring channels and waterways could not be tolerated. An examination of the 


\section{METHODES DE MESURE DE LA SALINITE}

Afin de contrôler le fonctionnement du modèle du point de vue de la salinité, il est nécessaire de comparer la répartition longitudinale de la salinité dans le modèle, avec celle existant dans la nature. La répartition verticale étant tout aussi importante, elle doit être vérifiée également. par des prises d'échantillons à la surface, à mi-profondeur, et au voisinage du fond, en plusieurs points différents, au cours d'un cycle de marée. Ces prises d'échantillons se font le mieux au moyen d'un tube en verre, comportant une échelle graduée en fonction des valeurs "nature», et relié à une poire en caoutchouc servant à aspirer l'échantillon. La plus précise méthode d'analyse de ces ćchantillons est celle par titration, de Knudsen [9]:

$$
\mathrm{AgNO}_{3}+\mathrm{NaCl}=\mathrm{AgCl}+\mathrm{NaNO}_{3}
$$

Cette méthode présente cependant l'inconvénient d'exiger à la fois beaucoup de temps et un personnel nombreux, dès que le nombre d'échantillons à analyser devient important. Une méthode assez rapide et précise consiste à employer un conductimetre d'un modèle couramment vendu dans le commerce. Cet appareil fonctionne suivant le principe du pont de Wheatstone et permet de mesurer la conductivité d'un échantillon de deux manières différentes: l'une consiste à obtenir une indication directe de la conductivité, ce qui permet, connaissant la température, de déterminer le taux de salinité; l'autre (estimée être la plus précise des deux méthodes), consiste à comparer l'échantillon avec un échantillon de référence, de concentration saline connue. Notons que les températures de ces deux échantillons doivent être les mêmes, ce qui s'obtient aisćment en laissant immergée pendant un certain temps dans l'eau du modèle, l'éprouvette contenant l'échantillon de référence. Afin d'assurer la meilleure précision possible, il paraît intéressant d'employer pour les mesures, la partie centrale de l'échelle de lecture de l'appareil et l'expérience montre que des solutions à $5,10,15,20$ et $30 \%$ de sel, dans $1000 \mathrm{~g}$ de solution, sont indiquées pour la constitution des échantillons de référence; en effet, ces dosages permettent d'obtenir une précision de $\pm 0,1 \%$. Rappelons, également, que l'eau douce amenée au modèle proviendra, normalement, du réseau urbain le plus proche, et qu'elle contiendra, par conséquent, déjà des sels dissous, dont la nature et la quantité varieront suivant la localité. Les échantillons de référence servant à la détermination des taux de salinité au moyen d'un conductimètre devront, par conséquent, être préparés avec cette même eau, et non avec de l'eau distillée.

La condition essentielle à respecter, pour un modèle de salinité, est que les phénomènes de densité soient reproduits correctement. Nous en parlons ici, parce qu'il se peut que, dans certains cas étudiés sur modele, la température des eaux des affluents d'eau douce soit supérieure, ou inférieure à celle de l'eau de mer; dans ces conditions, il appartiendrait de compenser cette différence de température en «corrigeant»la répartition de la salinité. Bien que de tels cas ne se présentent sans doute que rarement, il parait néanmoins bon de ne pas les perdre de vue, étant donné qu'un écart de température de $5{ }^{\circ} \mathrm{F}$ correspond à une différence de $1 \%$ dans le taux de salinité.

\section{REPRESENTATION DES COURANTS DE DENSITÉ PAR DES SUSPENSIONS STABLES D'ARGILE}

Le principal inconvénient de l'eau salée pour la reproduction des courants de densité dans les modèles, provient du fait qu'elle est très corrosive. Même des appareils situés à une dizaine de mètres du modèle n'échappent guère à cette corrosion et les appareils de mesure employés sur le modèle mème, étant de construction très délicate, en souffrent également. Par conséquent un choix très soigneux s'impose pour les matériaux de fabrication des appareils de mesure et de génération des marées destinés à servir sur les modèles à eau salée.
On a donc cherché à reproduire les courants de densité par d'autres moyens, en particulier en étudiant la possibilité de remplacer le sel par des suspensions stables d'argile. La plus grande partie de ces études a été effectuée par le «Waterloopkunding Laboratorium» à Delft (Pays-Bas) [10]; ceci est d'ailleurs tout à fait logique, étant donné que la ville de Delft se trouve dans une région située au-dessous du niveau de la mer, de sorte que l'évacuation d'eau saline dans les chenaux et les canaux de la région n'aurait pu être tolérée. L'examen de la 
method of simulating density currents by stable clay suspensions reveals that this procedure would be ideal for fixed-bed model studies, but the presence of clay in a model with a sandy bed might tend to inhibit the movement of the sand due to deposition of fine particles between larger grains. Another serious defect is that the model operator cannot see through the water. A graph showing concentrations of clay suspensions of comparable density to sodium chloride solutions is shown in Fig. 7. It will be seen that to achieve the equivalent of a density of 30 p.p.th of salt would require a concentration as high as 36,000 p.p.m. of clay.

\section{MEANS OF REDUCING ENTRANCE LENGTHS OF TIDAL MODELS}

It was mentioned earlier in the report that in order to reproduce the salinity distribution correctly in the system it is necessary to place the tide generator downstream of the point of no salinity change from H.W. to L.W. by a distance approximately equal to that travelled by a float per flood or ebb tide in this part of the estuary. This is not always convenient because it might mean that a length of estuary has to be included which is of little interest. In addition it might be found necessary to reduce the model scales in order to meet this requirement.

There are various ways of minimising this difficulty in which the tidal limit at the seaward end of the model can be placed further upstream. The argument is based on the fact that it is possible to extend the mixing and entry length outside the model into the tide generator. Most hydraulic models are either fitted with pneumatic tide generators or weir-type generators. The former type (Ref. [11]) consists of an inverted box placed across the seaward end of the model, and the ebb and flow of the tide is produced by extracting air from the tide generator. If there is complete mixing in the tide generator, then at H.W. the salt water in the tide-box will be displaced like a piston into the estuary, producing no salinity changes at the seaward limit from H.W. to L.W. If, however, the tide-box is fitted with a number of horizontal partitions, as shown in Figure $8 a$, and the concentrated brine is added in the position shown, then it should be possible to «wrap» the water into the tide generator and reduce the mixing that takes place, thereby setting up a salinity distribution in the tide generator itself. Under this system it will be seen that there will then be a change in salinity from H.W. to L.W. at the tidal Jimit. This means that the tidal limit can be placed further upstream in the estuarine system. The same argument can be applied to weir-type generators (Ref. [12]) and has been proved to work in the case of the Mersey model. Here the tidal volume of the system was accommodated in a sump constructed underneath the model (Fig. 8 b). Vertical baffles were placed in the sump as shown, and the concentrated brine added at the position indicated. In this

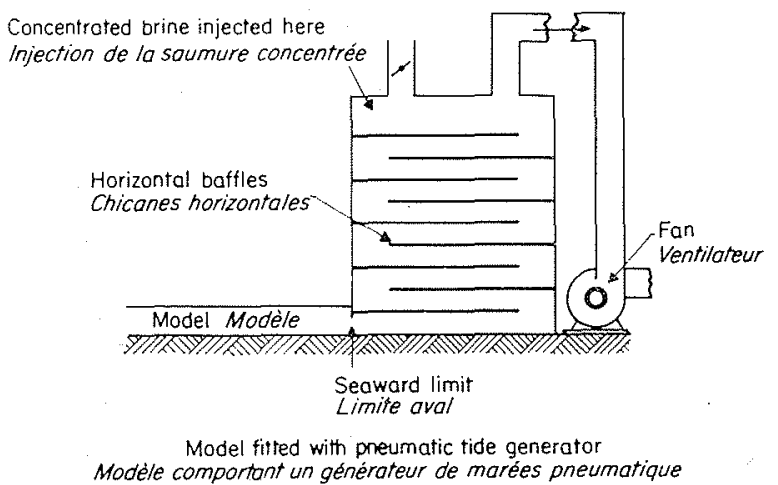

(a)

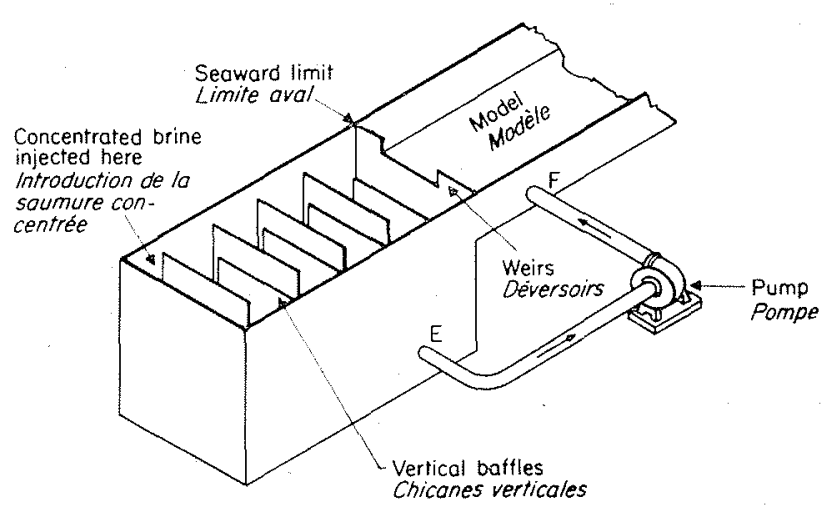

Model fitted with weir - type tide generator Modète comportant un générateur de marées ḋ déversoir

(b)

Fig. 8

Methods of reducing entrance length in tidal models.

Réduction des longuears d'entrée ana modeles à marée,

way a salinity distribution was set up outside the model. It is important in such a case, however, to make sure that the pump circuit EF is as short as possible, thus avoiding the mixing of more and less saline water during the course of a tide. Another means of increasing the steepness of the salinity gradient outside the tide generator is to induce greater mixing by placing folded wire gauze in the entrance channel to the model. 


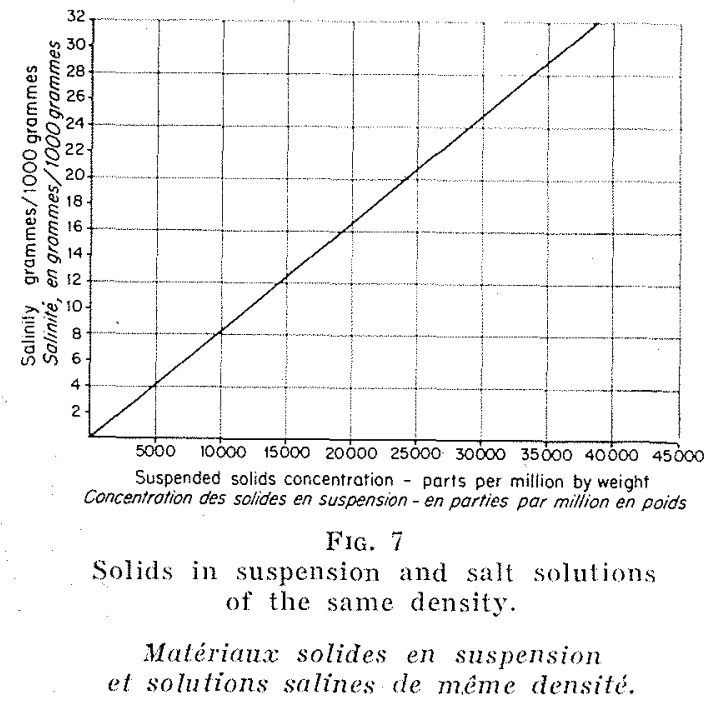

MOYENS PERMETTANT DE RÉDUIRE LES LONGUEURS D'ENTRÉE DES MODÉLES A MARÉE

Nous avons déjà vu qu'il est nécessaire, pour que la reproduction de la répartition de la salinité, dans le modèle, soit valable, d'implanter le générateur de marée à une distance, à l'avant du point d'égalité des taux de salinité aux hautes et aux basses eaux, à peu près égale à la distance parcourue par un flotteur pendant un flux (ou reflux), dans cette mème partie de l'estuaire. Or, cette condition risque parfois d'être gềnante, en rendant nécessaire la reproduction, sur le modèle, de tonte une partie de l'estuaire ne présentant pratiquement aucun intérêt, ainsi qu'une réduction éventuelle des échelles du modèle.

En repoussant la limite de marée aval du modèle plus loin vers l'amont, par l'une ou l'autre de diverses méthodes, il est possible de résoudre partiellement cette difficulté. Cette notion est basée sur la possibilité de comprendre, dans la longueur d'entrée et de mélange (laquelle se trouve à l'extérieur du modèle proprement dit) l'espace intérieur de l'appareil de marée. La plupart des modèles hydrauliques comportent des générateurs de marée, soit pneumatiques, soit à déversoir. Le premier type [11] consiste en une boîte inversée, disposée en travers à la limite aval du modèle, les courants de flux et de reflux étant reproduits en soutirant de l'air à l'appareil. Si le brassage se fait à fond, à l'intérieur de l'appareil, aux hautes eaux, son contenu d'eau salée pénètrera dans l'estuaire à peu près comme un «piston», sans qu'il y ait variation, à la limite aval, des taux de salinité correspondant aux hautes eaux et aux basses représentation des courants de densité au moyen de suspensions stables d'argile, montre bien que cette méthode conviendrait idéalement pour les modèles à fond fixe, mais que, par contre, dans un modèle à fond sableux, les particules fines d'argile, en se déposant parmi les gros grains de sable, risqueraient de freiner le mouvement de ce sable. Un deuxième inconvénient de cette méthode est que la présence de l'argile rend l'eau du modèle opaque, gênant ainsi toute observation visuelle. L'abaque de la figure 7 représente les concentrations d'argile en suspension correspondant à des solutions de chlorure de sodium de densité analogue. On y voit qu'une suspension d'argile de même densité qu'une solution saline à $30 \%$, devrait déjà être concentrée à $36 \%$. eaux. Par contre, si l'on prévoit, à l'intérieur de la «boîte à marées », un certain nombre de chicanes horizontales (tel que le montre la figure $8 a$ ), et si on introduit la saumure à l'endroit indiqué sur cette même figure, il devrait être possible "d'envelopper » l'eau dans ce générateur de marée, et ainsi d'y réduire le brassage, de manière à ce qu'il s'établisse déjà, à son intérieur, une certaine répartition de la salinité. On concoit que, dans ces conditions, les taux de salinité, à la limite de la marée, ne seront plus les mêmes aux hautes eaux et aux basses eaux; on pourra, par conséquent repousser cette limite plus loin, vers l'amont, dans l'estuaire. Ce même raisonnement est également valable pour les générateurs de marée à déversoir [12]. Il a été appliqué au modèle de la Mersey, dans lequel un réservoir disposé sous le modèle servait à emmagasiner le volume d'eau nécessaire pour la reproduction de la marée (fig. 8 b). Ce réservoir comportait, à l'intérieur, une série de chicanes verticales, et l'introduction de la saumure concentrée se faisait à l'endroit indiqué sur la figure. Cette disposition permettait d'établir une répartition de la salinité déjà à l'extérieur du modèle. Il est important, toutefois, que la longueur du circuit de pompage (EF) soit, dans une telle disposition, aussi réduite que possible, afin d'éviter le mélange des eaux plus et moins salées, au cours d'une marée. Il est également possible de raidir le gradient de salinité, à l'extérieur du générateur de marée, en provoquant un brassage plus intense, au moyen d'une toile métallique disposée dans le chenal d'entrée du modèle. 


\section{REFERENCES}

[1] Keтchus B. H. - The exchange of fresh and salt water in tidal estuaries. Journal of Marine Re. search, vol. 10, No, 1, pp. 18-38, 1951.

2] Schultz E. A. and Simmons H. B. - Fresh water, salt water, density currents, a major cause of siltation in estuaries. Committee on Tidal $\mathrm{Hy}$ dranlics, Corps of Engineers, U.S. Army, Technical Bulletin No. 2, April 1957.

[3] Pritchard D. W. - A review of our present knowledge of the dynamics and flushing of estuaries. Chesapeake Bay Institute of the John Hopkins University, Technical report 4, Mareh 1952.

[4] Pritchand D.W. - Salinity distribution and circulation in the Chesapeake Bay estuarine system. Journal of Marine Research, vol. 11, page 106. 1952.

[5] Aввотт M. R. - Salinity effects in estuaries. Sears Foundation. Journal of Marine Research, vol. 18. number 2, October 30, 1960, pp. 101-111.
6] Inglis and Aluns. - The regimen of the Thames estuary as affected by currents, salinities and river flows. Proc. Instn, Civ. Engrs, vol. 7, pp. 827-876.

[7] Kevlegan G.H. - Model laws for density currents. National Burean of Standards, Progress reports $1-3$

[8] Desalting of brackish water. Water and Water En gineering, October 1957 , pp. 435-438.

[9] Knepses M. - Hydrographical Tables.

10] Abraham G, and Diepruis J.G.H.R. - Stable clay suspensions as a substitute for sea water in model tests on density curxents. Publication No. 21. Hydraulics Laboratory, Delft, April 1959.

11? Wrnis M.J. and Young G.A.J. - Pneumatic tide generator. The Engineer, 25th July 1952, pp. 133137.

[12] Controlled-weir tide generator. Hydraulics Research, 1956 , p. 45; London, H.M.S.O., 1957.

\section{NOTRE FRONTISPICE}

\section{(Cf. p. 610 .)}

GAUSS (1777.1855)

Gauss est probablement celui, parmi les savants de son époque, qui fit pretuve de la plus grande précocité : à l'áge de trois ans, il calculait tracait des fourcs peonetrigues et résolvait dé des problènes numérioues Celo présarenit les dons de celu des proble tracait des fires que plus tar

Charles Frédéric Gauss, qui naquit à Brunswick le 23 avril $177 \%$, professa successivenent à Götingen et à Helnstaedt, avait ume maniere bien à lui d'aborder les problènes, de leur donner des solutions absolument neuves, generales, completes, applised matiran.

Presque en meme temps que Lerendre il imacina la méthode Presque en mene temps que Legendre, il inagina la méthode des moindres carrés; le calcul des probabilites lui doit la loi de repartion des crreurs, tractite par la courbe en cloche connute sous le nom de "courbe de Gauss", qui est devenue un élénent

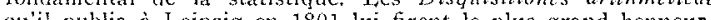
gu publa d leipzig en 180 lu hrent le plas gand honneur. On a pa cependant hi teprocher un style partors obscur et her I1 fut lun as pe lo soniers a signaler des simaux a l'aide des counonts galvanigues Inventeur de des sicliotrope du nave Thelotrope a du magnetometre, ses travalux sur le magnetisme, qui ont acdus depuis lors tant dimportance en matiere deced'intensité d'un champ magnétique.

Gauss mourut à Göttingen le 23 février 1855. Il était membro associé etranger de l'Académie des Sciences de Paris depuis 1820

\section{GAUSS $(1777.1855)$}

Gauss weas probably the most precocious scicntist of his cra: at the age of three he was already doing calculations, drawing geometric figures and solaing numerical problems. These were portents of the gifts of a man whom Laplace was later to cal "the greatest mathematician in Elurope".

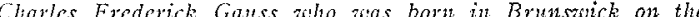
$23 r d$ of Aprii 1777 and held professorships frot at Göttingen and then at Helmstaedt, had his ow'n atay aptroaching problems and finding completely new, gencral and complete solutions, appli cable in all ases: in this his motto atas "Panca, sed matwa". Amost simultanoonsly aith Legendre he discovered the method of least squares and probability theory owes to him the law of the frequency of crrors, knouen as "Gauss's curve", which has since become an essential tool of the statistician. The Discuisi tiones arithmeticae which he published in Leipatg in 1801 repre. sents the full fordering of his talonts. Fis style can sometimes, however, be actused of being cressively obscwe and hermetic 1ii kceping with his of ten intractable and reserved character.

The inventor of the heliotrope and the magnetometer, his work on magnetisn. which has since acquired such importance in the industrial use of electricity, led later to the choice of his name to describe the unit of intensity of a magnetic ficld.

Gauss died in Gottingen on the $23 r d$ of Fobruary, 1855. He had been an associated foreign nember of the Paris Academy of Science since 1820 